\title{
Article/Artigo
}

\section{Antituberculosis drug-induced hepatotoxicity: a comparison between patients with and without human immunodeficiency virus seropositivity}

\author{
Hepatotoxicidade induzida pelos tuberculostáticos: comparação em pacientes com e sem \\ soropositividade para o vírus da imunodeficiência humana
}

\section{Natalia Saldanha Magalhães Coca ${ }^{1}$, Marcelo Silva Oliveiraa ${ }^{2}$, Izabela Voieta ${ }^{1}$, Carlos Maurício de Figueiredo Antunes $^{1}$ and José Roberto Lambertucci ${ }^{1}$}

\begin{abstract}
Introduction: The prevalence and risk factors for rifampin, isoniazid and pyrazinamide hepatotoxicity were evaluated in HIV-infected subjects and controls. Methods: Patients with tuberculosis ( $30 \mathrm{HIV}$ positive and $132 \mathrm{HIV}$ negative), aged between 18 and 80 years-old, admitted to hospital in Brazil, from 2005 to 2007, were selected for this investigation. Three definitions of hepatotoxicity were used: I) a 3-fold increase in the lower limit of normal for alanine-aminotransferase (ALT); II) a 3-fold increase in the upper limit of normal (ULN) for ALT, and III) a 3-fold increase in the ULN for ALT plus a 2-fold increase in the ULN of total bilirubin. Results: In groups with and without HIV infection the frequency of hepatotoxicity I was $77 \%$ and $46 \%$, respectively $(p<0.01)$. Using hepatotoxicity II and III definitions no difference was observed in the occurrence of antituberculosis drug-induced hepatitis. Of the 17 patients with hepatotoxicity by definition III, 3 presented no side effects and treatment was well tolerated. In $8(36.4 \%)$ out of 22 , symptoms emerged and treatment was suspended. Alcohol abuse was related to hepatotoxicity only for definition I. Conclusions: Depending on the definition of druginduced hepatitis, HIV infection may or may not be associated with hepatotoxicity. The impact that minor alterations in the definition had on the results was impressive. No death was related to drug-induced hepatotoxicity. The emergence of new symptoms after initiating antituberculosis therapy could not be attributed to hepatotoxicity in over one third of the cases.
\end{abstract}

Key-words: Hepatotoxicity. Antituberculosis drugs. Human immunodeficiency virus. Antiretroviral drugs. Hepatitis. Tuberculosis.

\section{RESUMO}

Introdução: Avaliou-se a prevalência e os fatores de risco para hepatotoxicidade aos tuberculostáticos em pacientes HIV positivos e controles. Métodos: Selecionou-se 162 pacientes com tuberculose, tratados com rifampicina, isoniazida e pirazinamida, na faixa etária de 18 a 80 anos, internados em hospital público no Brasil, entre 2005 e 2007. Eles foram divididos em dois grupos: 30 infectados pelo HIV e 132 controles. Adotou-se três definições para hepatotoxicidade: I) aumento de três vezes no valor inferior normal da alanina-aminotransferase (ALT); II) aumento de três vezes no valor superior normal (VSN) da ALT; III) aumento de três vezes no VSN da ALT e duas vezes no VSN da bilirrubina total. Resultados: Nos grupos com e sem infecção pelo HIV, a frequência de hepatotoxicidade I foi de $77 \%$ e $46 \%$, respectivamente $(p<0,01)$. Para as definições II e III a frequência de hepatotoxicidade não diferiu entre os grupos estudados. De 17 pacientes com hepatotoxicidade induzida por droga (definição III), três não apresentaram sintomas e o tratamento foi mantido sem intercorrências. Oito $(36,4 \%)$ de 22 indivíduos apresentaram efeitos colaterais e interromperam o tratamento, mas não apresentavam hepatotoxicidade pela definição III. $\mathrm{O}$ abuso deálcool associou-se à hepatotoxicidade apenas para a definição I. Conclusões: Na dependência da definição escolhida, a infecção pelo HIV pode ou não associar-se à hepatotoxicidade. Foi grande o impacto que pequenas alterações na definição de hepatotoxicidade tiveram nos resultados. Nenhuma morte associou-se ao uso de tuberculostáticos. O surgimento de sintomas não pôde ser atribuído aos tuberculostáticos em um terço dos casos.

Palavras-chaves: Hepatoxicidade. Tuberculostáticos. Vírus da imunodeficiência humana adquirida. Drogas antirretrovirais. Hepatite. Tuberculose.

1. Graduate Course in Health Science: Infectology and Tropical Medicine, Faculty of Medicine, Federal University of Minas Gerais, Belo Horizonte, MG. 2. Eduardo de Menezes Hospital, Minas Gerais Health Foundation, Belo Horizonte, MG.

Address to: Dr. José Roberto Lambertucci. Dept ${ }^{\circ}$ de Clínica Médica/FM/UFMG. Av. Alfredo Balena 190, 30130-100 Belo Horizonte, MG

Phone: $55313337-7781$

e-mail: lamber@uai.com.br

Received in 13/02/2010

Accepted in 06/10/2010

\section{INTRODUCTION}

Eighty five thousand cases of tuberculosis and 30,000 new cases of HIV infection were reported in Brazil in $2008^{1}$. Tuberculosis is the most common opportunistic disease in HIV-infected patients ${ }^{2-8}$.

In Africa, tuberculosis has been reported to be the worst epidemic faced by local health authorities ever. The average incidence of tuberculosis increased from 149 to 343 cases per 100,000 inhabitants between 1990 and $2005^{9}$.

The usual drug regimens for treating tuberculosis are the same as those recommended for HIV coinfected patients. However, therapeutic failures and recurrences have been more frequently reported among the latter?.

Toxic hepatitis is the most severe adverse reaction to antituberculosis drugs. It usually installs in the first few weeks of treatment, in parallel with liver necrosis, which may evolve to encephalopathy and death. The risk factors most frequently associated with druginduced hepatitis are: old age, undernourishment, chronic alcohol abuse, $\mathrm{B}$ and $\mathrm{C}$ viral hepatitides and the use of antiretroviral therapy ${ }^{10,11}$.

Increased hepatotoxicity with antituberculosis drugs has been reported in HIV-infected patients by some authors ${ }^{12,13}$; however, others do not corroborate this association ${ }^{14-18}$. In addition, a diversity of definitions for toxic hepatitis are currently in use and numerous drug regimens are involved in treating tuberculosis.

In this study, the prevalence and risk factors for hepatotoxicity to rifampin, isoniazid and pyrazinamide were evaluated in HIV-infected subjects.

\section{METHODS}

This is a case control study. Medical records of 450 adult patients admitted to the Eduardo de Menezes Hospital in Belo Horizonte, MG, Brazil, from 2005 to 2007 , were examined. Of these, 288 were excluded: 14 with viral hepatitides and 274 with pulmonary diseases other than tuberculosis. 
Thus, 162 patients with tuberculosis ( $30 \mathrm{HIV}$ positive and $132 \mathrm{HIV}$ negative), with ages ranging from 18 to 80 years, were selected for this investigation (Figure 1).

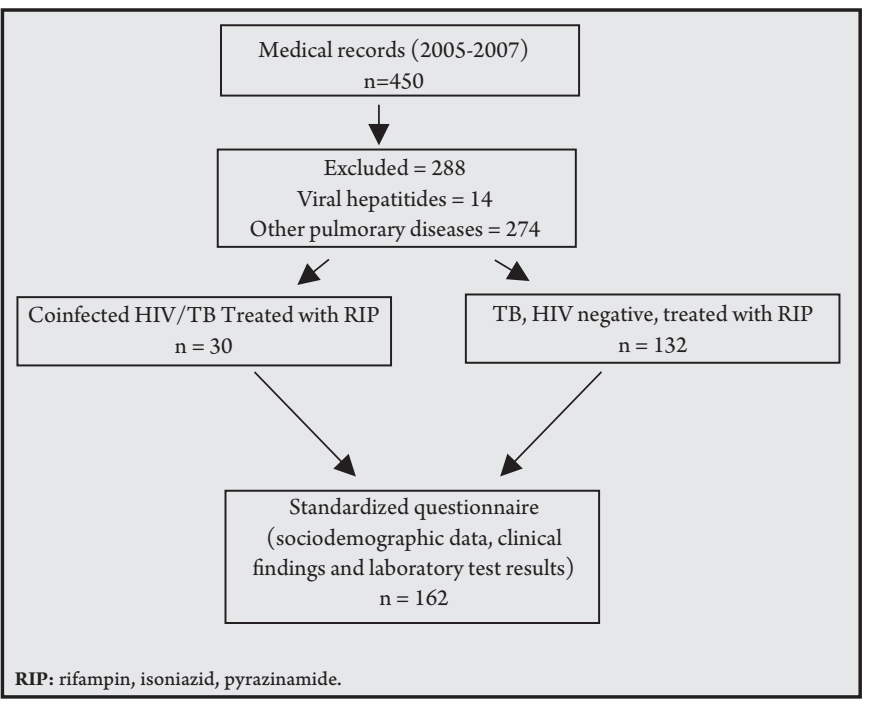

FIGURE 1 - Flow chart of patients with tuberculosis selected for the present study.

\section{Definition of hepatotoxicity}

Three definitions of hepatoxicity were used: I, a 3-fold increase in the lower limit of normal for alanine-aminotransferase (ALT); II, a 3-fold increase in the upper limit of normal (ULN) for ALT; and III, a 3-fold increase in the ULN for ALT plus a 2 -fold increase in the ULN of total bilirubin ${ }^{19-21}$.

\section{Alcohol abuse}

Excessive alcohol use was defined as the ingestion of more than $60 \mathrm{~g}$ of alcohol per day, which is the equivalent to $140 \mathrm{~mL}$ of a local distilled sugarcane derived drink, pinga, or two bottles of beer ${ }^{22}$.

\section{Data collection}

Information obtained from the medical records of patients admitted to the Hospital Eduardo de Menezes, Belo Horizonte, Brazil, from 2005 to 2007, were transferred to a data bank and analyzed by SPSS 12.0. For each patient, a standardized questionnaire was filled out with sociodemographic data, clinical findings and laboratory test results.

\section{Laboratory and radiological tests}

Hemogram and erythrocyte sedimentation rate; amylase, bilirrubin, BUN, LDH, alkaline phosphatase, glucose, alanine aminotransferase (Merck-Selectra and Roche-Cobas-Mira), HBsAg, anti$\mathrm{HBcAg}$ and anti-HCV were tested in sera samples (AXSYM HCV 3.0. Abbott Laboratories, Brasil) and chest $\mathrm{x}$-rays were taken.

\section{HIV serology and lymphocyte count}

Enzyme-linked immunosorbent assay (ELISA) and western-blot were used according to Brazilian Ministry of Health recommendations. For the western-blot, a commercial kit was used (HBB 404 HEMOBIO, HIV-1 Imunoblot, Westernblot, Empresa Brasileira de Biotecnologia SA). CD4+ and CD8+ counts in blood were quantified by flow cytometry (Coulter, Becton and Dickinson, Facscalibur flow cytometer, San Diego, California, USA).

\section{Culture for Mycobacterium tuberculosis}

The samples were decontaminated using monosodium phosphate and trisodium phosphate (modified Corper \& Stoner method) ${ }^{23,24}$ and were concentrated by centrifugation. Subsequently, smears prepared from an aliquot of the sediment were submitted to staining
(Ziehl-Neelsen and auramine $)^{25,26}$ after which they were examined under microscopy. A quantity $(0.1 \mathrm{~mL})$ of the sediment was added to at least two tubes containing Löwenstein-Jensen (LJ) medium, which were incubated at $37^{\circ} \mathrm{C}$ for up to eight weeks. The results were described using a semiquantitative scale. The strains isolated were identified by means of the growth inhibition test using p-nitro-alphaacetylamino-beta-hydroxypropiophenone (NAP) in the BACTEC 460 system (Becton Dickinson Microbiology Systems, Sparks, MD, USA) and by means of other phenotyping tests (morphological analysis of colonies and classical biochemical tests) ${ }^{27}$.

\section{Diagnosing tuberculosis}

The diagnosis of tuberculosis was accepted when the agent was identified in smear/culture of biological material (blood, tissue, sputum) or based on clinical and radiological evidence associated with a definitive response to antituberculosis treatment.

\section{Tuberculin test}

Purified protein derivative (PPD) test was administered by injecting a $0.1 \mathrm{~mL}$ volume containing $5 \mathrm{TU}$ (tuberculin units) under the skin of the forearm. The test was read between 48 and $72 \mathrm{~h}$ after injection. A positive induration from 0 to $4 \mathrm{~mm}$ was considered negative; 5 to $9 \mathrm{~mm}$ of induration was considered a positive weak skin test result and above $9 \mathrm{~mm}$ a strong response.

\section{Statistical analysis}

Data from the questionnaires were transferred to a data bank using EpiData 3.1 (EpiData Association, Odense, Denmark) and analyzed by the Statistical Package for Social Sciences (SPSS) 12.0 (SPSS inc, IBM Company, Chicago, Illinois). As a first step, descriptive analysis (frequency tables and exploratory data analysis for qualitative and quantitative variables, respectively) was conducted. Cases and controls were compared using the Chi square or Fisher exact (qualitative variables) and Mann-Whitney (quantitative variables) tests. Pre and posttreatment information was analyzed by the McNemar (qualitative) and Wilcoxon tests. Comparison of the time until hepatotoxicity between the two groups was done using Kaplan-Meier curves and log-rank test. Logistic regression models were performed to identify risk factors associated with hepatotoxicity. For variables to enter the model, a $p$ value of 0.2 was used; to remain in the final model, a $p$ value of 0.05 was adopted. Odds ratios (OR) and respective $95 \%$ confidence intervals $(95 \% \mathrm{CI})$ were used to estimate hepatotoxicity risk. Model adjustment was tested by the Hosmer \& Lemeshow technique ${ }^{28}$.

\section{Ethical}

The present investigation was approved by the Human Research Ethical Boards of the Eduardo de Menezes Hospital and the School of Medicine of the Federal University of Minas Gerais.

\section{RESULTS}

\section{Sociodemographic and clinical data}

The mean age was $35.7 \pm 0.6$ and $43.8 \pm 3.9$ years-old for the HIV positive and negative groups, respectively $(\mathrm{p}<0.003)$. For weight, skin color, sex and alcohol abuse, no significant difference was observed between the groups studied (Table 1).

\section{Pulmonary or extrapulmonary tuberculosis}

Sixteen $(53.3 \%)$ out of 30 patients presented pulmonary tuberculosis in the HIV group and 122 (92.4\%) out of 132 in the HIV negative $(p=0.003)$. The other organs affected were the central nervous system, intestines, spine and lymph nodes. 
TABLE 1 - Sex, age, skin color, alcohol abuse and body weight of 162 patients (HIV positive and negative) with tuberculosis admitted to the Eduardo de Menezes Hospital in Belo Horizonte, Minas Gerais, Brazil, from 2005 to 2007.

\begin{tabular}{|c|c|c|c|c|c|}
\hline \multirow[b]{3}{*}{ Characteristics } & \multicolumn{4}{|c|}{ Study groups } & \multirow[b]{3}{*}{$\mathrm{p}$} \\
\hline & \multicolumn{2}{|c|}{$\mathrm{HIV}+(\mathrm{n}=30)$} & \multicolumn{2}{|c|}{ HIV- $(n=132)$} & \\
\hline & $\mathrm{n}$ & $\%$ & $\mathrm{n}$ & $\%$ & \\
\hline Sex (male) & 23 & 76.7 & 94 & 71.2 & 0.55 \\
\hline Age (median, yr) & 36 & $29-41^{*}$ & 42 & $33-54$ & 0.03 \\
\hline \multicolumn{6}{|l|}{ Skin color } \\
\hline white & 3 & 10 & 18 & 14 & \\
\hline black & 2 & 6.7 & 11 & 8 & 0.56 \\
\hline other & 2 & 7 & 20 & 15 & \\
\hline ignored & 23 & 77 & 83 & 63 & \\
\hline Alcohol abuse & 15 & 68 & 68 & 64 & 0.99 \\
\hline Body weight (median) & 54 & $48-58^{*}$ & 53 & $48-60^{*}$ & 0.52 \\
\hline
\end{tabular}

\section{Comorbidities}

Twenty one patients presented diabetes mellitus, 17 presented systemic arterial hypertension, 2 presented heart failure and 1 presented chronic renal failure. No relation was observed between these comorbidities and hepatotoxicity.

\section{Hepatotoxicity}

Hepatotoxicity I occurred in 23 (77\%) out of $30 \mathrm{HIV}$ positive patients and in 60 (45.5\%; p < 0.01) out of $132 \mathrm{HIV}$ negative patients. Hepatotoxicity II occurred in $6(20 \%)$ out of $30 \mathrm{HIV}$ positive patients and in $12(9 \% ; \mathrm{p}=0.107)$ out of $132 \mathrm{HIV}$ negative patients. Hepatotoxicity III occurred in $6(20 \%)$ out of $30 \mathrm{HIV}$ positive patients and in $11(8.3 \%$; $=0.09)$ out of 132 HIV negative patients.

\section{Liver enzymes}

A significant increase in liver enzymes after initiating treatment (ALT, AST, GGT, alkaline phosphatase and total bilirubin) was reported for both groups $(\mathrm{p}<0.01)$.

\section{Factors associated to hepatotoxicity}

Hepatotoxicity was more frequent in men. Using definition I, alcohol abuse was equally associated with hepatotoxicity in both groups.

\section{Treatment interruption}

Antituberculosis treatment was suspended in 22 patients; $7(23.3 \%)$ out 30 were HIV positive and 15 (11.4\%) out of 132 were HIV negative $(p=0.08)$. Fourteen $(63.6 \%)$ out of 22 fulfilled the criteria for toxic hepatitis by definition III. The remaining 8 (36.4\%), who did not have hepatotoxicity by definition III, stopped treatment for tuberculosis because they presented symptoms (nausea, vomiting, abdominal pain and hyporexia) which precluded further use of antituberculosis therapy. They presented comorbidities (4 with toxoplasmosis, 1 with cor pulmonale and 3 with CMV infection) and prescribed drugs for these diseases may be the explanation for their complaints.

Table 2 lists the 17 patients with hepatotoxicity III. In 14, treatment was suspended because they developed symptomatic toxic hepatitis, while in 3 asymptomatic individuals, treatment with antituberculosis drugs was maintained and well tolerated.
TABLE 2 - Patients with hepatotoxicity according to definition III*, 3 weeks after treatment for tuberculosis with rifampin, isoniazid and pyrazinamide (HIV positive/negative) at the Eduardo de Menezes Hospital, Belo Horizonte, Minas Gerais, Brazil, 2005-2007.

\begin{tabular}{lccc}
\hline Patients & $\begin{array}{c}\text { ALT } \\
(\mathrm{UI} / \mathrm{L})\end{array}$ & $\begin{array}{c}\text { Total bilirubin } \\
(\mathrm{mg} / \mathrm{dL})\end{array}$ & $\begin{array}{c}\text { HIV serological } \\
\text { status }\end{array}$ \\
\hline 1 & 333 & 2.7 & - \\
2 & 279 & 4.8 & - \\
3 & 205 & 4.4 & + \\
4 & 199 & 3.2 & - \\
5 & 910 & 2.9 & - \\
6 & 260 & 2.5 & - \\
7 & 307 & 3.6 & + \\
8 & 313 & 6.3 & - \\
9 & 382 & 5.2 & - \\
10 & 235 & 2.3 & - \\
11 & 200 & 3.6 & - \\
12 & 882 & 4.5 & - \\
13 & 306 & 2.5 & + \\
14 & 214 & 2.2 & + \\
15 & 277 & 3.5 & + \\
16 & 516 & 4.9 & + \\
17 & 1,270 & 5.7 & - \\
\hline & & & + \\
\hline
\end{tabular}

*definition III: a 3-fold increase in the upper limit of normal for ALT (65UI/L) plus a 2 -fold increase in the upper limit of normal for total bilirubin $(2 \mathrm{mg} / \mathrm{dL})$.

ALT: alanine-aminotransferase.

\section{DISCUSSION}

The frequency of hepatotoxicity caused by rifampin, isoniazid and pyrazinamide varied, in the present study, according to the definition used. For hepatotoxicity I, 77\% (23 out of 30) of the HIV-infected group and $45.5 \%$ (60 out of 132) of the noninfected group developed toxic hepatitis $(\mathrm{p}=0.002)$. For definitions II and III, no statistical difference in toxic hepatitis was observed between HIV-infected and noninfected patients.

The definition of drug induced hepatitis differs in the literature, making comparisons between studies difficult. The World Health Organization $(\mathrm{WHO})^{1}$, for example, divides the intensity of hepatitis into four grades: I (slight), ALT $\leq 2.5$ times the ULN; II (mild), ALT 2.6-5.0 the ULN; III (moderate), 5-10 times the ULN; and IV (severe), $>10$ times the ULN. In this study, three patients (cases 5, 12 and 17) presented severe hepatitis according to the WHO definitions (Table 2). The American Society for the Study of the Liver states that a three-fold increase in ALT above the ULN plus a two-fold increase in the ULN of total bilirubin and verification of clinical data are necessary to define toxic hepatitis ${ }^{29}$. For the Brazilian Ministry of Health ${ }^{30}$, a three-fold increase in ALT and AST, with symptoms or jaundice would be necessary to define hepatotoxicity.

In the recommendations published by the Ministry of Health of Brazil ${ }^{30}$ prior to 2009 , the normal value to be used in the definition of toxic hepatitis were not clearly defined. It simply stated, “... when liver enzymes are 3 times over the normal value”. In the present study, when the lower limit of normal for ALT is considered, naturally, the number of patients with hepatotoxicity increases compared to the ULN and an association with HIV infection and alcohol abuse was observed. When using the lower limit of normal, sensitivity increases and specificity decreases. 
In the new directives published by the Ministry of Health of Brazil in 200931, hepatotoxicity that occurs after the onset of antituberculosis therapy was defined as an increase in ALT serum levels $>5$ times the upper limit of normal (ULN) (with or without jaundice) or jaundice (with or without ALT increase). In Table 2 it is possible to see that only $6(35.3 \%)$ out of the 17 patients listed would fulfill the criterion of ALT $>5$ times the ULN.

Eighty-three (51.2\%) out of 162 patients in both groups (HIV positive and negative) presented hepatotoxicity when definition I was used. After 15 days, 17 (20.5\%) of the 83 developed hepatotoxicity by definition III. This finding is worth mentioning because, once a patient presents hepatotoxicity by definition I, given enough time, $1 / 5$ will develop toxic hepatitis by definition III and, in most cases, treatment for tuberculosis would be suspended.

In the literature, the prevalence of hepatotoxicity to antituberculosis drugs ranges widely from $5 \%$ to $27 \% \%^{12,32-36}$. One possible explanation is that different definitions were used for drug-induced hepatitis ${ }^{37-39}$. Here, hepatotoxicity ranged from $8.3 \%$ to $45.5 \%$ in the HIV-negative group and from $20 \%$ to $77 \%$ in the HIV-positive group, depending on the definition applied.

Therefore, depending on the definition of hepatotoxicity, this potentially severe adverse reaction to antituberculosis drugs, may or may not be identified ${ }^{34}$. Evidence both in favor of ${ }^{12,13,15}$ and against a role for HIV infection in the frequency of toxic hepatitis caused by antituberculosis therapy has been reported ${ }^{18,32,38}$.

Treatment for tuberculosis was suspended for 22 patients, $14(63.6 \%)$ of whom fulfilled the criteria for toxic hepatitis by definition III. In the remaining 8 (36.4\%), who did not have hepatotoxicity according to definition III, treatment for tuberculosis was suspended because they presented symptoms (nausea, vomiting, abdominal pain and hyporexia) that precluded the continued use of the drugs. They presented comorbidities (4 with toxoplasmosis, 1 with cor pulmonale and 3 with CMV infection) and the drugs prescribed for these conditions may partially account for their complaints.

Seventeen out of 136 patients had toxic hepatitis according to definition III and in 14, RIP was suspended; however, in three asymptomatic patients, treatment for tuberculosis was maintained (ALT of 205, 199 and 235U/L) and no complications evolved. This confirms the importance of using associated clinical findings (e.g., vomiting, jaundice, nausea, fever) to suspend treatment.

While investigating hepatotoxicity caused by antiretroviral drugs in $868 \mathrm{HIV}$-infected patients in Africa, Hoffman et a ${ }^{13}$ observed that the frequency of toxic hepatitis was highest in patients concomitantly treated for tuberculosis. Information concerning the concomitant use of antiretroviral drugs and antituberculosis therapy was not possible in the present investigation, because data obtained from the medical records regarding drug interaction were scarce and unreliable.

Seventeen (10.5\%) out of 162 patients died during treatment for tuberculosis: two in the HIV-infected group and 15 in the controls $(p=0.45)$. Five $(22.7 \%)$ out of the 22 patients who did interrupt treatment died thereafter: seven $(28.6 \%)$ were HIV positive and $15(20 \%)$, HIV negative $(\mathrm{p}=0.66)$. Based on previous reports, our hypothesis was that death would be more frequent in HIVinfected individuals ${ }^{12}$. Two explanations for our incorrect prediction may be offered: 1) following the introduction of highly active antiretroviral therapy, mortality decreased in HIV-infected patients with tuberculosis, and 2) since tuberculosis is more common in the HIV-infected group, physicians tend to consider the diagnosis of tuberculosis earlier and treat their patients at once, therefore, resulting in better survival.

It has been well documented that alcohol abuse is associated with higher toxic hepatitis in patients treated with antituberculosis drugs $^{40}$. In this work, alcohol abuse was confirmed as associated with tuberculosis treatment, although toxicity was not increased in the HIV-infected group.

The frequency of toxic hepatitis was not different for definitions II and III (only one patient had hepatotoxicity according to definition II and not III). The difference between definitions II and III is the presence of jaundice in definition III. This kind of result raises the question of whether jaundice is really important in the diagnosis of toxic hepatitis caused by antituberculosis drugs.

To our knowledge, this is the first investigation comparing three distinct definitions of antituberculosis drug -induced hepatotoxicity. Analysis of the findings obtained suggest that the definition of hepatotoxicity outlined by the Brazilian Ministry of Health should be updated and standardized ${ }^{41}$.

In conclusion, depending on the definition of toxic hepatitis, HIV infection may or may not be associated with hepatotoxicity. The impact that minor alterations in the definition; i.e., upper or lower limits of normal for ALT and how many times these normal values $(2 \mathrm{X}, 3 \mathrm{X}, 5 \mathrm{X})$, had on the results is impressive. No death was related to hepatotoxicity. Alcohol abuse is associated with toxic hepatitis, but not with HIV infection and mortality was not higher in the HIV-infected group. Symptoms are important in the definition of toxic hepatitis; however, the emergence of new symptoms following the onset of antituberculosis therapy could not be attributed to hepatotoxicity in over one third of the cases studied.

\section{CONFLICT OF INTEREST}

The authors declare that there are no conflicts of interest.

\section{FINANCIAL SUPPORT}

This work was supported by the Coordenação de Aperfeiçoamento de Pessoal de Nível Superior (CAPES) and Conselho Nacional de Desenvolvimento Científico e Tecnológico (CNPq), Brazil.

\section{REFERENCES}

1. World Health Organization. Global tuberculosis control: a short update to the 2009 report. WHO Press; WHO/HTM/TB/2009.426.

2. LambertucciJR, Rayes AA, Gerspacher-Lara R. Salmonella-S. mansoni association in patients with acquired immunodeficiency syndrome. Rev Inst Med Trop Sao Paulo 1998; 40:233-235.

3. Herzog H. History of tuberculosis. Respiration 1998; 65:5-15.

4. Dye C, Scheele S, Dolin P, Pathania V, Raviglione MC. Consensus statement. Global burden of tuberculosis: estimated incidence, prevalence, and mortality by country. WHO Global Surveillance and Monitoring Project.JAMA 1999; 282:677-686.

5. Lambertucci JR, Rayes AA, Nunes F, Landazuri-Palacios JE, Nobre V. Fever of undetermined origin in patients with the acquired immunodeficiency syndrome in Brazil: report on 55 cases. Rev Inst Med Trop S Paulo 1999; 41:27-32.

6. Teixeira Jr AL, Nobre V, Lambertucci JR. Respiratory failure due to opportunistic diseases in AIDS. Rev Soc Bras Med Trop 2002; 35:411-412.

7. Nobre V, Braga E, Rayes A, Serufo JC, Godoy P, Nunes N, et al. Opportunistic infections in patients with AIDS admitted to an university hospital of the Southeast of Brazil. Rev Inst Med Trop Sao Paulo 2003; 45:69-74. 
8. Aaron L, Saadoun D, Calatroni I, Launay O, Mémain N, Vincent V, et al. Tuberculosis in HIV-infected patients: a comprehensive review. Clin Microbiol Infect 2004;10:388-398.

9. Nunn P, Williams B, Floyd K, Dye C, Elzinga G, Raviglione M. Tuberculosis control in the era of HIV. Nat Rev Immunol 2005; 5:819-826.

10. Comitê Técnico-Científico de Assessoramento à Tuberculose e Comitê Assessor para Coinfecção HIV-Tuberculose.Guia de Vigilância Epidemiológica. Brasília: Ministério da Saúde; 2002. v.1.p.31-33.

11. Rodrigues MC, Viotti JB, Braga RF, Lourenço LF, Antunes CM, Lambertucci JR. $\mathrm{HIV} / \mathrm{HCV}$ coinfection in Infectious Disease Units in Mozambique and Brazil: a comparative study. Rev Soc Bras Med Trop 2008; 41:518.

12. Pedral-Sampaio DB, Martins Netto E, Alcântara AP, Souza J, Moura L, Brites C, et al. Use of standard therapy for tuberculosis is associated with increased adverse reactions in patients with HIV. Braz J Infect Dis 1997;1:123-130.

13. Hoffmann CJ, Charalambous S, Thio CL, Martin DJ, Pemba L, Fielding KL, et al. Hepatotoxicity in an African antiretroviral therapy cohort: the effect of tuberculosis and hepatitis B. AIDS 2007; 21:1301-1308.

14. Askgaard DS, Wilcke T, Døssing M. Hepatotoxicity caused by the combined action of isoniazid and rifampicin. Thorax 1995; 50:213-214.

15. Breen RA, Miller RF, Gorsuch T, Smith CJ, Schwenk A, Holmes W, et al. Adverse events and treatment interruption in tuberculosis patients with and without HIV co-infection. Thorax 2006; 61:791-794.

16. El-SadrWM, Tsiouris SJ. HIV-associated tuberculosis: diagnostic and treatment challenges. Semin Respir Crit Care Med 2008; 29:525-531.

17. Saraceni V, King BS, Cavalcante SC, Golub JE, Lauria LM, Moulton LH, et al. Tuberculosis as primary cause of death among AIDS cases in Rio de Janeiro, Brazil. Int J Tuberc Lung Dis 2008; 12:769-772.

18. Perriëns JH, St Louis ME, Mukadi YB, Brown C, Prignot J, Pouthier F, et al. Pulmonary tuberculosis in HIV-infected patients in Zaire. A controlled trial of treatment for either 6 or 12 months. N Engl J Med 1995; 332:779-784.

19. Yew W, Leung C. Antituberculosis drugs and hepatotoxicity. Med Bull 2007; 12:7-9.

20. American Thoracic Society/Centers for Disease Control and Prevention/ Infectious Diseases Society of America. Treatment of Tuberculosis. Am J Respir Crit Care Med 2003; 167:603-662.

21. Fernandez-Villar A, Sopena B, Fernandez-Villar J. The influence of risk factors on the severity of antibuterculosis drug-induced hepatotoxicity. Int J Tuberc Lung Dis 2004; 8:1499-1505.

22. Lambertucci JR, Cota GF, Pinto-Silva RA, Serufo JC, Gerspacher-Lara R, Costa Drummond S, et al. Hepatosplenic schistosomiasis in field-based studies: a combined clinical and sonographic definition. Mem Inst Oswaldo Cruz 2001; 96 (suppl 1):147-150

23. Centro Panamericano de Zoonosis. Manual de normas y procedimientos tecnicos para la bacteriologia de la tuberculosis: Parte I. La muestra, El examen microscopico. CEPANZO. Notas Tecnicas, no 26/Rev. 1. Buenos Aires: CEPANZO; 1988.

24. Smithwick RW. Laboratory manual acid-fast microscopy. Atlanta (GA): Public Health Service, Center for Disease Control, Bureau of Laboratories; 1976.

25. Union International Contra la Tuberculosis. Guia tecnico para recoleción, conservación y transporte de las muestras de esputo y examen por microscopia direct para la tuberculosis. Bol Un Int Tuberc 1978; 53 (supl 2):1-21.

26. Fundação Nacional de Saúde. Centro de Referência Professor Helio Fraga. Manual de Bacteriologia da Tuberculose. $2^{\text {nd }}$ ed. Rio de Janeiro: Ministério da Saúde; 1994.

27. Siddiqi SH. BACTEC 460 TB system. Product and procedure manual, revision D. Sparks (MD): Becton Dickinson Diagnostic Systems; 1995.

28. Dupont WD. Statistical Modeling for Biomedical Researchers, $2^{\text {nd }}$ ed. Cambridge: Cambridge University Press UK; 2009.

29. Navarro VJ, Senior JR. Drug-related hepatotoxicity. N Engl J Med 2006; 354:731-739.

30. Ministério da Saúde. Programa Nacional de Controle da Tuberculose. Brasília: Editora Ministério da Saúde; 2002.

31. Ministério da Saúde. Guia de Vigilância Epidemiológica da Tuberculose. Brasília: Ministério da Saúde; 2009.
32. Chaisson RE, Clermont HC, Holt EA, Cantave M, Johnson MP, Atkinson J, et al. Six-month supervised intermittent tuberculosis therapy in Haitian patients with and without HIV infection. Am J Respir Crit Care Med 1996; 154:1034-1038.

33. Nathwani RA, Kaplowitz N. Drug hepatotoxicity. Clin Liver Dis 2006; 10:207-217.

34. Pessayre D, Bentata M, Degott C, Nouel O, Miguet JP, Rueff B, et al. Isoniazidrifampin fulminant hepatitis. A possible consequence of the enhancement of isoniazid hepatotoxicity by enzyme induction. Gastroenterology 1977; 72:284-289.

35. Saukkonen JJ, Cohn DL, Jasmer RM, Schenker S, Jereb JA, Nolan CM, et al. An official ATS statement: hepatotoxicity of antituberculosis therapy. Am J Respir Crit Care Med 2006; 174:935-952.

36. Schaberg $\mathrm{T}$. The dark side of antituberculosis therapy: adverse events involving liver function. Eur Respir J 1995; 8:1247-1249.

37. Tostmann A, Boeree MJ, Harries AD, Sauvageot D, Banda HT, Zijlstra EE. Short communication: antituberculosis drug-induced hepatotoxicity is unexpectedly low in HIV-infected pulmonary tuberculosis patients in Malawi. Trop Med Int Health 2007; 12:852-855.

38. Tostmann A, Boeree MJ, Aarnoutse RE, de Lange WC, van der Ven AJ, Dekhuijzen R. Antituberculosis drug-induced hepatotoxicity: concise up-to-date review. J Gastroenterol Hepatol 2008; 23:192-202.

39. Yew WW, Leung CC. Antituberculosis drugs and hepatotoxicity. Respirology 2006; 11:699-707.

40. Willner IR, Reuben A. Alcohol and the liver. Curr Opin Gastroenterol $2005 ; 21: 323-330$.

41. Oliva VM, Cezário GAG, Cocato RA, Marcondes-Machado J. Pulmonary tuberculosis: hematology, serum biochemistry and the relation with the disease duration. J Venom Anim Toxins Incl Trop Dis 2008; 14:71-81. 